\title{
Response Surface Methodology used in the Optimization of RP-HPLC Condition for separation of Carmine and Rhodamine B
}

\author{
Reyna Nuvitasari1,2, Abdul Rohman ${ }^{1,3^{*}}$ and Sudibyo Martono ${ }^{1}$
}

1. Department of Pharmaceutical Chemistry, Faculty of Pharmacy, Universitas Gadjah Mada, Yogyakarta 55281, Indonesia.

2. The National Agency of Drug and Food Control, , Republic of Indonesia, Jl. Karang Menjangan Surabaya, East Java 60286, Indonesia.

3. Institute of Halal Industry and System (IHIS), Universitas Gadjah Mada, Yogyakarta 55281, Indonesia.

\begin{tabular}{l} 
Info Article \\
\hline Submitted: 27-06-2019 \\
Revised: 25-09-2019 \\
Accepted: 15-10-2019 \\
*Corresponding author \\
Abdul Rohman \\
Email: \\
abdul_kimfar@ugm.ac.id
\end{tabular}

\section{INTRODUCTION}

The use of coloring agent in many cosmetic products such as lipsticks, eye shadows, eyeliners, blushers, and nail polishes is common, especially for woman. Most of the cosmetics products contain one or more coloring agents (dyes) in order to provide the desired colors (Weisz et al., 2018). The use of coloring agents in cosmetics are mainly to increase acceptability, to identify the cosmetics products as well as to fit the standard preparations and products stability (Allam and Kumar, 2011). The dyes used in cosmetics products are subject to a wide range of restrictions from the main regulatory authorities such as US Food and Drug Administration (FDA) in the United States of
America, the European Commission (EC) in the European Union (EU), and the Ministry of Health, Labor and Welfare (MHLW) in Japan. In Indonesia, the restriction of coloring agents in cosmetics was regulated by The National Agency of Drug and Food Control, Republic of Indonesia (Nohynek et al., 2010). Carmine (CI 75470) [CAR] is one of the permitted coloring agents used in cosmetics including lipsticks, but in some susceptible people, the contact of the human body with CAR can produce allergic reactions, sensitization or photosensitization (DiCello et al., 1999; Miyakawa et al., 2017). In addition, Rhodamine B (CI 45170) [RDB], is prohibited as a coloring agent in cosmetic products in the United States, EU, and Indonesia 
(Gagliardi et al., 1996; Tatebe et al., 2014). Due to its similarity color, CAR is frequently replaced by RDB (Kanekar and Khale, 2014). The chemical structures of CAR and RDB (Figure 1). As a consequence, analytical methods capable of identifying and quantifying of CAR and RDB must be developed and optimized in order to ensure the cosmetic safety.

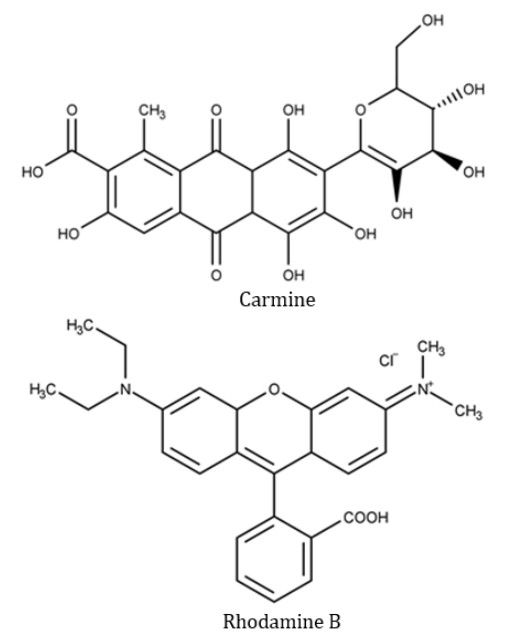

Figure 1. The chemical structures of carmine (CI 75470) and Rhodamine B (CI 45170)

Reversed phase-high performance liquid chromatography (RP-HPLC) with detectors of mass spectrometry with several ionization techniques (Sun et al., 2007; Feng et al., 2011; Li et al., 2013) and photo-diode array (Rastogi et al., 1997; Miranda-Bermudez et al., 2014) has been widely reported for the analysis of coloring agents. However, the developed RP-HPLC method during the optimization of HPLC condition used the conventional method. Experimental design has been used as tools for method optimization in HPLC, especially for simultaneous component such as CAR and RDB. The experimental design has been widely used to optimize conditions for chromatographic separation in analytical chemistry because it has the ability to reveal possible interactions among variables so that it is able to save time and to simplify work (Bezerra et al., 2008). A simple method using Response Surface Method was developed for the extraction and determination of coloring pigments of CAR in cochineals (Dactylopius coccus Costa). Two-level factorial design was used in order to optimize the solvent extraction parameters of temperature, time, methanol concentration in the extractant mixture, and the number of extractions (Gonzalez et al., 2002). Single factor experiment was also applied to optimize the experimental conditions. Wang et al. (2015) used various parameters to achieve the best extraction efficiency. Through the single factor tests, the authors selected four factors ( $\mathrm{pH}$, volume, flow rate and eluent flow rate). In the present study, RP-HPLC was optimized using experimental design approach based on response surface methodology using Central Composite Design (CCD). The Experimental design allows predicting the optimum condition of RP-HPLC in short experiment and time (Shaji and Shah, 2016). This design can determine correlation between factors and responses (output) that are resulted in the experiment process.

\section{MATERIALS AND METHODS}

The reference standards of carmine (CAR) and Rhodamine $\mathrm{B}$ (RDB) were obtained from the national agency of drug and food control (NADFC), Republic of Indonesia. All solvents used for mobile phase were of HPLC grade and obtained from E. Merck (Darmstadt, Germany). Aquabidest was obtained from Ikapharmindo (Indonesia).

\section{Preparation of reference standards}

For preparation of stock solution, an approximately of $5.00 \mathrm{mg}$ of each CAR and RDB was accurately weighed using analytical balance (Metler Toledo MX5) with sensitivity of $0.01 \mathrm{mg}$ and was added into volumetric flask $50 \mathrm{~mL}$ and dissolved with mobile phase until volume. This solution was then used for preparing calibration curve.

\section{HPLC instrumentation}

CAR and RDB were analyzed using chromatograph of Shimadzu LC 20AD equipped with photo-diode array (PDA) (Shimadzu LC 20AD, M20A PDA Detector) at wavelength 245-600nm. The separation was achieved using Cosmosil $\mathrm{C}_{18}$ column ( $250 \mathrm{~mm} \times 4.6 \mathrm{~mm}$ i.d., $5 \mu \mathrm{m})$. The mobile phase used was acetonitrile-phosphate buffer $\mathrm{pH}$ $3.4(55: 45 \mathrm{v} / \mathrm{v})$ delivered isocratically at flow rate of $1.1 \mathrm{~mL} / \mathrm{min}$, using column temperature at $35^{\circ} \mathrm{C}$.

\section{Experimental design using CCD}

The experimental design based on response surface methodology (RSM) using central composite design (CCD) is used during HPLC method optimization because RSM can resolve HPLC separation-related problems which the number of factors is higher than 2 (Siregar et al., 2018). In this study, the optimization of RP-HPLC separation of CAR and RDB was studied using four factors (independent variables), i.e. 
Table I. Central Composite design using dependent variables of variation $\mathrm{pH}$ Buffer phosphate $\left(\mathrm{X}_{1}\right)$, ratio of acetonitrile $\left(\mathrm{X}_{2}\right)$, flow rate $\left(\mathrm{X}_{3}\right)$ and column temperature $\left(\mathrm{X}_{4}\right)$ with response variables of resolution $\left(\mathrm{Y}_{1}\right)$, tailing factor of carmine $\left(\mathrm{Y}_{2}\right)$, tailing factor rhodamin $\mathrm{B}(\mathrm{Y} 3)$, retention time carmine $\left(\mathrm{Y}_{4}\right)$, retention time rhodamine $\mathrm{B}\left(\mathrm{Y}_{5}\right)$, peak area carmine $\left(\mathrm{Y}_{6}\right)$, and peak area rhodamin B (Y7) used in HPLC optimization for separation of carmine and rhodamine $\mathrm{B}$.

\begin{tabular}{|c|c|c|c|c|c|c|c|c|c|c|c|c|}
\hline \multirow{3}{*}{ Std. } & \multirow{3}{*}{ Run } & \multirow{2}{*}{\multicolumn{4}{|c|}{ Dependent Variabel }} & \multicolumn{7}{|c|}{ Response } \\
\hline & & & & & & & armine & & & Rhodam & ne B & \\
\hline & & X1 & $\mathrm{X} 2$ & X3 & X4 & Y4 & Y6 & Y2 & Y5 & Y7 & Y3 & Y1 \\
\hline 12 & 1 & 2.8 & 55 & 1.1 & 35 & 2.587 & 83143 & 1.5 & 7.949 & 215190 & 0.98 & 7.851 \\
\hline 20 & 2 & 3.1 & 52.5 & 1 & 32.5 & 1.931 & 71231 & 1.43 & 5.757 & 188954 & 0.93 & 7.314 \\
\hline 10 & 3 & 3.1 & 52.5 & 1.2 & 32.5 & 2.121 & 76629 & 1.46 & 5.566 & 199772 & 0.98 & 6.638 \\
\hline 16 & 4 & 3.1 & 57.5 & 1 & 32.5 & 2.114 & 76082 & 1.5 & 5.892 & 198471 & 1.03 & 6.758 \\
\hline 21 & 5 & 3.1 & 57.5 & 1.2 & 32.5 & 2.033 & 69597 & 1.54 & 4.827 & 176922 & 1.03 & 6.088 \\
\hline 1 & 6 & 3.1 & 52.5 & 1 & 37.5 & 2.064 & 69271 & 1.54 & 6.404 & 177065 & 0.98 & 7.667 \\
\hline 6 & 7 & 3.1 & 52.5 & 1.2 & 37.5 & 2.105 & 75758 & 1.51 & 6.007 & 198351 & 1.05 & 6.782 \\
\hline 5 & 8 & 3.1 & 57.5 & 1.2 & 37.5 & 2.115 & 76279 & 1.52 & 5.866 & 199356 & 1.06 & 6.454 \\
\hline 22 & 9 & 3.1 & 57.5 & 1 & 37.5 & 2.3 & 78499 & 1.52 & 6.164 & 208283 & 1.06 & 6.426 \\
\hline 8 & 10 & 3.4 & 55 & 1.1 & 30 & 1.99 & 66778 & 1.59 & 6.545 & 173590 & 1.02 & 7.541 \\
\hline 29 & 11 & 3.4 & 55 & 0.9 & 35 & 2.292 & 80427 & 1.43 & 7.025 & 223066 & 0.96 & 7.626 \\
\hline 30 & 12 & 3.4 & 55 & 1.1 & 35 & 2.165 & 73136 & 1.6 & 6.103 & 187292 & 0.97 & 7.069 \\
\hline 7 & 13 & 3.4 & 55 & 1.1 & 35 & 2.108 & 75925 & 1.5 & 5.931 & 198834 & 1.04 & 6.649 \\
\hline 9 & 14 & 3.4 & 55 & 1.1 & 35 & 2.119 & 77036 & 1.49 & 5.94 & 198970 & 1.03 & 6.636 \\
\hline 13 & 15 & 3.4 & 55 & 1.1 & 35 & 1.924 & 70034 & 1.45 & 5.871 & 187293 & 0.96 & 7.137 \\
\hline 14 & 16 & 3.4 & 55 & 1.1 & 35 & 2.386 & 81311 & 1.59 & 5.709 & 210718 & 1.06 & 5.746 \\
\hline 4 & 17 & 3.4 & 55 & 0.9 & 35 & 2.303 & 81668 & 1.55 & 5.256 & 226995 & 1.01 & 5.467 \\
\hline 19 & 18 & 3.4 & 55 & 1.3 & 35 & 2.299 & 81780 & 1.55 & 5.289 & 227509 & 0.99 & 5.674 \\
\hline 23 & 19 & 3.4 & 50 & 1.1 & 35 & 1.798 & 64012 & 1.48 & 4.854 & 168374 & 1.01 & 6.244 \\
\hline 28 & 20 & 3.4 & 60 & 1.1 & 35 & 2.38 & 79865 & 1.59 & 7.939 & 207136 & 1.02 & 7.952 \\
\hline 3 & 21 & 3.4 & 55 & 1.1 & 40 & 1.989 & 67234 & 1.55 & 4.73 & 175039 & 1.06 & 5.532 \\
\hline 11 & 22 & 3.7 & 52.5 & 1 & 32.5 & 2.429 & 82229 & 1.57 & 5.612 & 214289 & 1.05 & 5.793 \\
\hline 15 & 23 & 3.7 & 52.5 & 1.2 & 32.5 & 2.143 & 77114 & 1.47 & 7.955 & 196954 & 0.98 & 9.064 \\
\hline 27 & 24 & 3.7 & 57.5 & 1.2 & 32.5 & 2.107 & 74396 & 1.49 & 5.401 & 217591 & 1.02 & 6.501 \\
\hline 17 & 25 & 3.7 & 57.5 & 1 & 32.5 & 2.307 & 80444 & 1.42 & 6.956 & 223812 & 0.93 & 7.884 \\
\hline 25 & 26 & 3.7 & 52.5 & 1 & 37.5 & 1.919 & 70172 & 1.51 & 4.437 & 189234 & 0.98 & 5.486 \\
\hline 18 & 27 & 3.7 & 57.5 & 1 & 37.5 & 1.922 & 70165 & 1.52 & 4.498 & 189214 & 1 & 5.206 \\
\hline 26 & 28 & 3.7 & 57.5 & 1.2 & 37.5 & 2.119 & 75974 & 1.6 & 4.456 & 202080 & 1.08 & 4.792 \\
\hline 2 & 29 & 3.7 & 52.5 & 1.2 & 37.5 & 2.575 & 92772 & 1.49 & 7.015 & 241244 & 1.03 & 6.956 \\
\hline 24 & 30 & 4 & 55 & 1.1 & 35 & 2.11 & 76113 & 1.52 & 6.068 & 198029 & 1.05 & 6.776 \\
\hline
\end{tabular}

$\mathrm{pH}$ buffer phosphate $\left(\mathrm{X}_{1}\right)$, ratio of acetonitrile $\left(\mathrm{X}_{2}\right)$, flow rate $\left(\mathrm{X}_{3}\right)$ and column temperature $\left(\mathrm{X}_{4}\right)$. While, the responses (dependent variables) evaluated were resolution between CAR and RDB $\left(\mathrm{Y}_{1}\right)$, tailing factor of CAR $\left(\mathrm{Y}_{2}\right)$, tailing factor of RDB $\left(\mathrm{Y}_{3}\right)$, retention time of CAR $\left(\mathrm{Y}_{4}\right)$, retention time of RDB ( $Y_{5}$ ), peak area of CAR ( $\left.Y_{6}\right)$ and peak area of $\operatorname{RDB}\left(\mathrm{Y}_{7}\right)$.

\section{Data analysis}

RSM using CCD together with statistical parameters was carried out using Design-Expert version 8.0.4.1. Factors were considered to affect the responses significantly if the value of coefficient of determination $\left(R^{2}\right) \geq 0.8$ and Adjusted $R^{2}$ value > 0.8 . The difference between Predicted $R^{2}$ with the Adjusted $\mathrm{R}^{2}$ must be less than 0.2 . The statistical test of independent t-test was used for comparing results obtained from CCD and from the actual experiments.

\section{RESULTS AND DISCUSSION}

RP-HPLC is a method of choice for analysis of CAR and RDB simultaneously due to its capability to provide the separation between CAR and RDB with acceptable sensitivity. 
Some factors affected HPLC separation of analytes, therefore, it is a need to optimize HPLC condition to get optimum separation with desired requirement. The general desired requirement are lower value tailing factor and retention time and higher values of resolution and peak area (Prabaningdyah et al., 2017). Conventionally, the optimization is performed using OVAT (One Variable in One Time) approach. OVAT is simple, however, this approach failed to identify the interaction among factors, as a consequence, the experimental design based on response surface methodology was employed to overcome this problem (Setyawan et al., 2018). One of commonly RSM approach used in HPLC separation is Box-Behnken Design (BBD), as used by Prabandiyah et al. (2018) for the optimization of HPLC separation among curcuminoids and Setyawan et al. (2018) for the separation of catechins and gallates.

CCD was performed using 30 runnings, employing 4 independent variables (factors), namely $\mathrm{pH}$ buffer phosphate $\left(\mathrm{X}_{1}\right)$, the acetonitrile ratio $\left(\mathrm{X}_{2}\right)$, flow rate $\left(\mathrm{X}_{3}\right)$, and column temperature $\left(\mathrm{X}_{4}\right)$. The responses (dependent variables) observed were resolution (Rs) between CAR and $\operatorname{RDB}\left(\mathrm{Y}_{1}\right)$, tailing factor of CAR $\left(\mathrm{Y}_{2}\right)$, tailing factor of $\mathrm{RDB}\left(\mathrm{Y}_{3}\right)$, retention time of CAR $\left(\mathrm{Y}_{4}\right)$, retention time

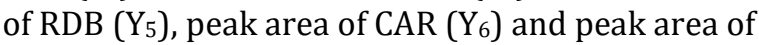
$\mathrm{RDB}\left(\mathrm{Y}_{7}\right)$. CCD using these factors and responses resulted during optimization (Table I).

\section{Response on resolution (Y1)}

Based on analysis of variance (ANOVA) results, the equation obtained using $\mathrm{X}_{1}, \mathrm{X}_{2}, \mathrm{X}_{3}$, and $\mathrm{X}_{4}$ as independent variables with resolution of peaks between CAR and RDB $\left(\mathrm{Y}_{1}\right)$ as response was:

$\sqrt{Y 1}=7.34-0.09 \mathrm{X} 1-0.08 \mathrm{X} 2-0.27 \mathrm{X} 3+0.01 \mathrm{X} 4$ $\left(\mathrm{R}^{2}\right.$ adjusted $\left.=0.9747\right)($ Eq.1)

Based on the above equation, the higher resolution $\left(\mathrm{Y}_{1}\right)$ could be obtained by increasing column temperature $\left(\mathrm{X}_{4}\right)$ and decreasing $\mathrm{pH}$ buffer phosphate $\left(\mathrm{X}_{1}\right)$, acetonitrile ratio $\left(\mathrm{X}_{2}\right)$, and flow rate $\left(X_{3}\right)$. The increasing column temperature has not increased $\mathrm{Y}_{1}$ significantly, but the decreasing flow rate has decreased significantly. P-values less than 0.05 indicated that model terms are significant. In this case $\mathrm{X}_{1}, \mathrm{X}_{2}, \mathrm{X}_{3}$ and $\mathrm{X}_{4}$ are significant model terms. The Predicted $\mathrm{R}^{2}$ of 0.9678 is in reasonable agreement with the Adjusted $\mathrm{R}^{2}$ of 0.9747 . Factors (independent variables) significantly affected the responses (dependent variables) if $R^{2} \geq 0.8$. The difference between Predicted $\mathrm{R}^{2}$ with the Adjusted $\mathrm{R}^{2}$ must be less than 0.2 . The contour plot of resolution of CAR and RDB and 3D surface graph as a result of variables of $\mathrm{pH}$ buffer phosphate, ratio of acetonitrile, flow rate and column temperature (Figure 2). The lower acetonitrile ratio, the lower resolution.

\section{Response of tailing factor carmine (Y2)}

Based on ANOVA results, the equation obtained for the quadratic model using $\mathrm{X}_{1}, \mathrm{X}_{2}, \mathrm{X}_{3}$, and $\mathrm{X}_{4}$ as independent variables with tailing factor of CAR (Y2) was:

$\mathrm{Y}_{2}=12.34-2.98 \mathrm{X}_{1}-0.23 \mathrm{X}_{2}+3.59 \mathrm{X}_{3}-0.09 \mathrm{X}_{4}+$ $0.03 \mathrm{X}_{1} \mathrm{X}_{2}-0.02 \mathrm{X}_{1} \mathrm{X}_{3}+0.01 \mathrm{X}_{1} \mathrm{X}_{4}-0.05 \mathrm{X}_{2} \mathrm{X}_{3}+$ $0.001 \mathrm{X}_{2} \mathrm{X}_{4}+0.01 \mathrm{X}_{3} \mathrm{X}_{4}+0.12 \mathrm{X}^{2}+0.001 \mathrm{X} 2^{2}-$ $0.43 X^{2}-0.001 X^{2} \quad$ (Adjusted $R^{2}=0.9306$ ) (Eq.2)

Based on the above equation, the lower response of tailing factor CAR $\left(\mathrm{Y}_{2}\right)$ could be obtained by decreasing flow rate $\left(\mathrm{X}_{3}\right)$ and increasing $\mathrm{pH}$ buffer phosphate $\left(\mathrm{X}_{1}\right)$, acetonitrile ratio $\left(\mathrm{X}_{2}\right)$, and column temperature $\left(\mathrm{X}_{4}\right)$. The decreasing flow rate has increased $\mathrm{Y}_{2}$ significantly, but the increasing other variables has not decreased significantly. The statistical results revealed that adjusted coefficient of determination (Adj. $\mathrm{R}^{2}$ ) obtained was $>0.8$, which was within the acceptable limits $\left(\mathrm{R}^{2}>0.8\right)$. This indicated that experimental model was good fit using polynomial equations. Based on ANOVA results, the variables of $\mathrm{X}_{1}, \mathrm{X}_{2}$ and $\mathrm{X}_{4}$ as well as interaction between $\mathrm{X}_{1} . \mathrm{X}_{2}$; $\mathrm{X}_{1} \mathrm{X}_{4} ; \mathrm{X}_{2} . \mathrm{X}_{3}$ and $\mathrm{X}_{2} . \mathrm{X}_{4}$ and quadratic form of $\mathrm{X}_{1}$ and $\mathrm{X}_{2}$ contributed significantly for response of $\mathrm{Y}_{2}(\mathrm{P}<$ 0.05). Figure 3 exhibited the contour plot of tailing factor of CAR and 3D surface graph as a results of variables of $\mathrm{X}_{1}, \mathrm{X}_{2}, \mathrm{X}_{3}$, and $\mathrm{X}_{4}$. The lower acetonitrile ratio and the higher $\mathrm{pH}$ buffer phosphate, the lower tailing factor for carmine (Figure 3).

\section{Response tailing factor Rhodamine $\mathrm{B}\left(\mathrm{Y}_{3}\right)$}

The equation obtained using $\mathrm{X}_{1}, \mathrm{X}_{2}, \mathrm{X}_{3}$, and $\mathrm{X}_{4}$ as independent variables with tailing factor of $\mathrm{RDB}\left(\mathrm{Y}_{3}\right)$ was linear model, in the form of:

$\mathrm{Y}_{3}=0.88-0.05 \mathrm{X}_{1}+0.01 \mathrm{X}_{2}-0.03 \mathrm{X}_{3}-0.006 \mathrm{X}_{4}$ (Adjusted $\mathrm{R}^{2}=0.4867$ ) (Eq.3).

Based on the above equation, $\mathrm{X}_{1}, \mathrm{X}_{2}, \mathrm{X}_{3}$, and $\mathrm{X}_{4}$ has not influenced the response of tailing factor RDB $\left(\mathrm{Y}_{3}\right)$ significantly. The Eq. 3 corresponded to the response of tailing factor of $\operatorname{RDB}\left(\mathrm{Y}_{3}\right)$. The statistic results for $\mathrm{Y}_{3}$ revealed that Adj. $\mathrm{R}^{2}$ obtained was $<0.8$, which was not acceptable. Based on ANOVA results, the variables of $\mathrm{X}_{3}$ has no interaction with response of $\mathrm{Y}_{3}$ (P Value $>0.05$ ). 

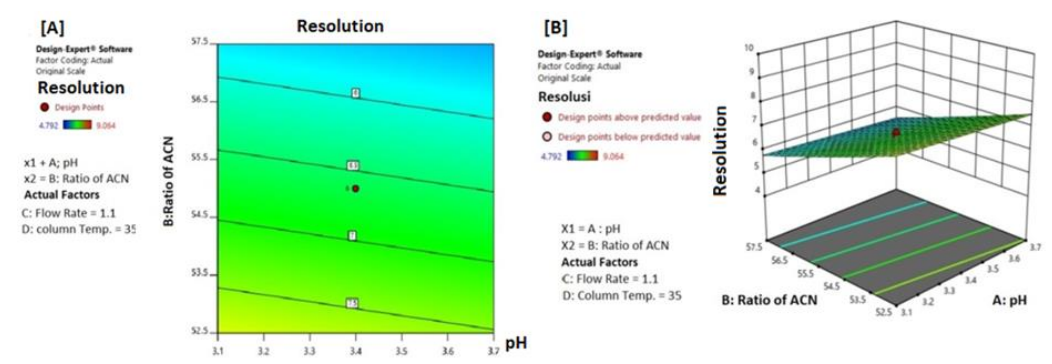

Figure 2. The contour plot of resolution of Carmine and Rhodamine B [A] and 3D surface graph [B] as a results of variables of $\mathrm{pH}$ Buffer phosphate, ratio of acetonitrile, flow rate and column temperature.
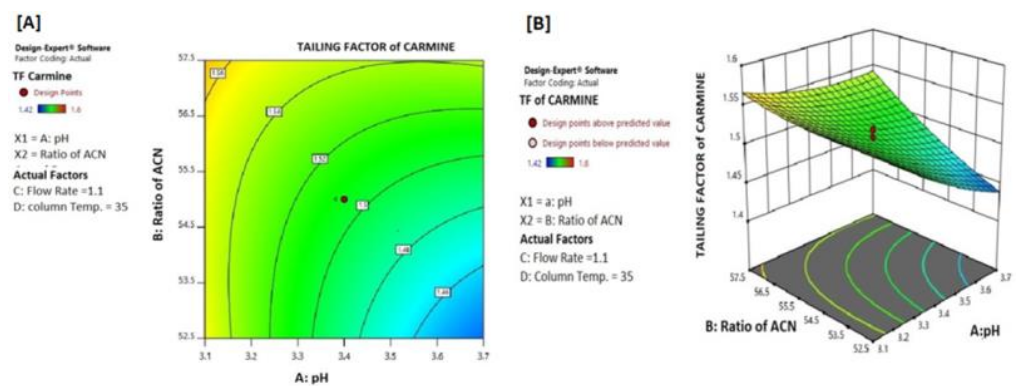

Figure 3. The contour plot of tailing factor of Carmine [A] and 3D surface graph [B] as a results of variables of pH Buffer phosphate (X1), ratio of acetonitrile (X2), flow rate (X3) and column temperature (X4).(X1), ratio of acetonitrile (X2), flow rate (X3) and column temperature (X4).
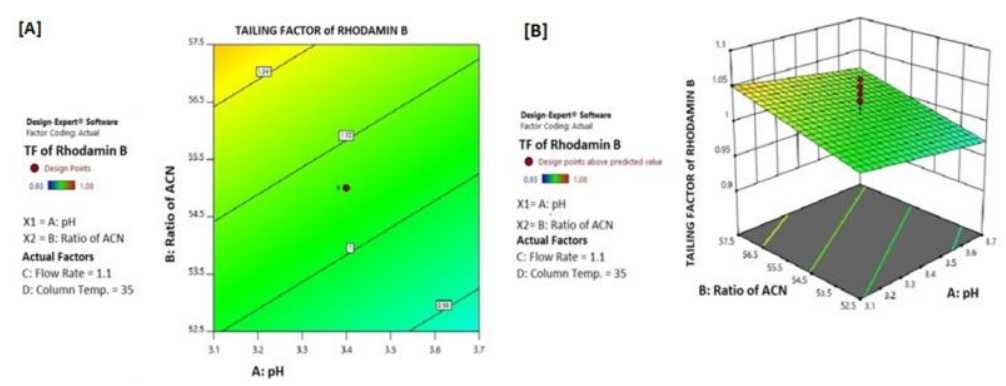

Figure 4. The contour plot of tailing factor of Rhodamine B [A] and 3D surface graph [B] as a results of variables of $\mathrm{pH}$ Buffer phosphate (X1), ratio of acetonitrile (X2), flow rate (X3) and column temperature $(\mathrm{X} 4)(\mathrm{X} 1)$, ratio of acetonitrile (X2), flow rate (X3) and column temperature (X4).
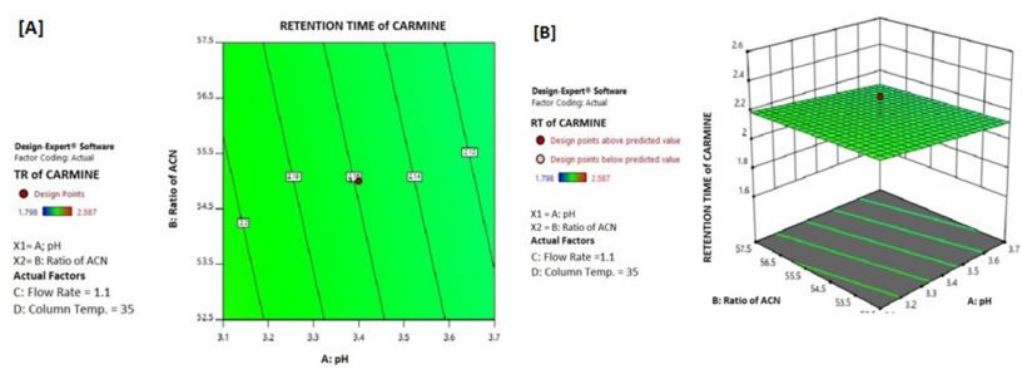

Figure 5. The contour plot of retention time of carmine [A] and 3D surface graph [B] as a results of variablesresult of variables of $\mathrm{pH}$ Buffer phosphate (X1), ratio of acetonitrile (X2), flow rate (X3) and column temperature (X4). 
[A]

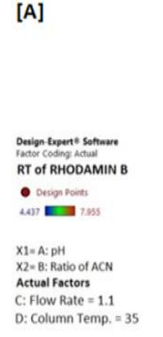

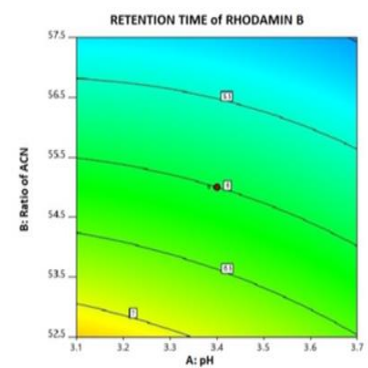

[B]

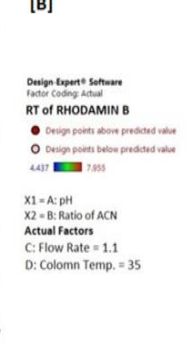

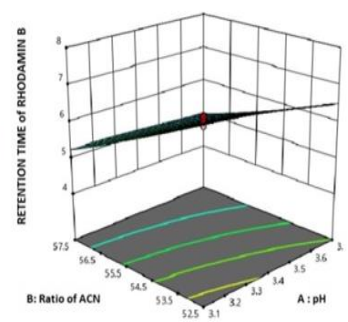

Figure 6. The contour plot of retention time of Rhodamine B $[\mathrm{A}]$ and 3D surface graph $[\mathrm{B}]$ as a result of $\mathrm{pH}$ buffer phosphate (X1), ratio of acetonitrile (X2), flow rate (X3) and column temperature (X4).
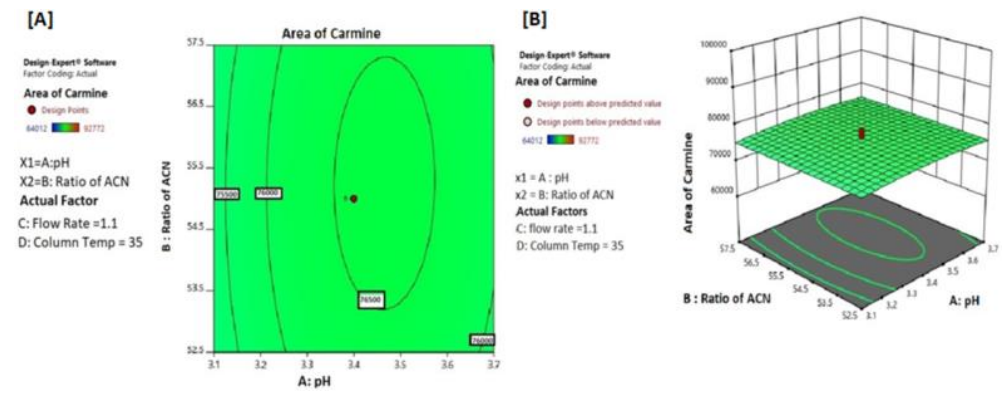

Figure 7. The contour plot of peak area of Rhodamine $B[A]$ and 3D surface graph [B] as a result of variables of $\mathrm{pH}$ buffer phosphate (X1), ratio of acetonitrile (X2), flow rate (X3) and column temperature (X4).
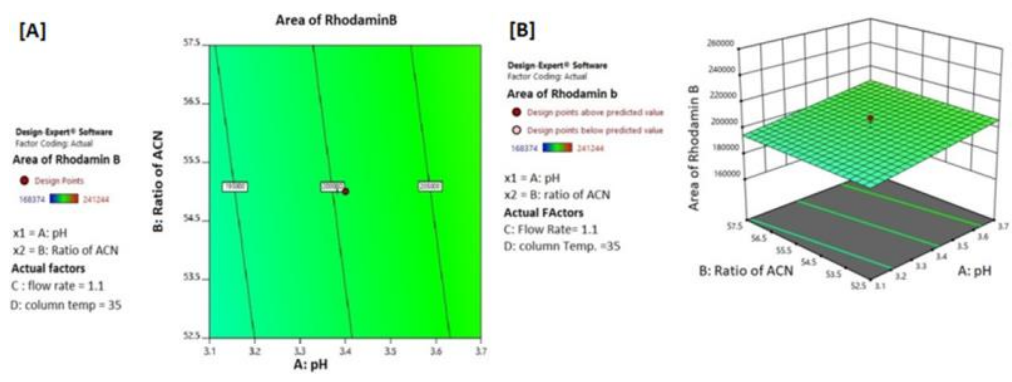

Figure 8. The contour plot of peak area of Rhodamine $B[A]$ and 3D surface graph $[B]$ as a results of variables of $\mathrm{pH}$ Buffer phosphate (X1), ratio of acetonitrile (X2), flow rate (X3) and column temperature (X4).

The contour plot of tailing factor of RDB [A] and 3D surface graph [B] as a results of variables of $\mathrm{pH}$ Buffer phosphate, ratio of acetonitrile, flow rate and column temperature (Figure 4). Based on the Eq. 3, pH buffer phosphate $\left(\mathrm{X}_{1}\right)$ have higher influence for resolution than others. The lower acetonitrile ratio and the higher $\mathrm{pH}$ buffer phosphate, the lower tailing factor for RDB (Figure 4).

\section{Response of retention time of Carmine $\left(\mathrm{Y}_{4}\right)$}

Based on ANOVA results, the equation obtained for the linear relationship between $\mathrm{X}_{1}, \mathrm{X}_{2}$,
$\mathrm{X}_{3}$, and $\mathrm{X}_{4}$ as independent variables with retention time of CRM (Y4) was:

$\mathrm{Y}_{4}=4.84-0.15 \mathrm{X}_{1}-0.001 \mathrm{X}_{2}-1.98 \mathrm{X}_{3}+0.007 \mathrm{X}_{4}$ (Adjustable $\mathrm{R}^{2}=0.9152$ ) (Eq.4)

Based on the above equation, the lower retention time of CAR $\left(\mathrm{Y}_{4}\right)$ can be obtained by increasing flow rate. The increasing column temperature has not significantly increased $\mathrm{Y} 4$. Based on ANOVA results, the statistic results for $\mathrm{Y}_{4}$ informed that adj. $R^{2}$ was $>0.8$. The variables of $X_{1}$, $\mathrm{X}_{2}, \mathrm{X}_{3}$, and $\mathrm{X}_{4}$ was in the linear form and contributed significantly for response of $\mathrm{Y}_{4}(\mathrm{P}<0.05)$. Figure 5 
exhibited the contour plot of retention time of CAR and 3D surface graph as a result of variables of $X_{1}$, $\mathrm{X}_{2}, \mathrm{X}_{3}$, and $\mathrm{X}_{4}$. The change of acetonitrile ratio and $\mathrm{pH}$ buffer phosphate did not influence to retention time of CAR significantly (Figure 5).

\section{Response of retention time of Rhodamine B ( $\left.\mathrm{Y}_{5}\right)$}

Based on ANOVA results, the equation obtained using X1, X2, X3, and X4 as independent variables with retention time $\mathrm{RDB}\left(\mathrm{Y}_{5}\right)$ as response was:

$\mathrm{Y}_{5}=106.29-6.29 \mathrm{X}_{1}-2.47 \mathrm{X}_{2}-33.42 \mathrm{X}_{3}+0.63 \mathrm{X}_{4}+$ $0.15 \mathrm{X}_{1} \mathrm{X}_{2}+1.54 \mathrm{X}_{1} \mathrm{X}_{3}-0.007 \mathrm{X}_{1} \mathrm{X}_{4}+0.48 \mathrm{X}_{2} \mathrm{X}_{3}+$ $0.003 \mathrm{X}_{2} \mathrm{X}_{4}-0.02 \mathrm{X}_{3} \mathrm{X}_{4}-0.65 \mathrm{X} 1^{2}+0.009 \mathrm{X} 2^{2}-1.26 \mathrm{X}^{2}$ - 0.01X42 (Adjustable $\mathrm{R}^{2}=0.9884$ ) (Eq.4).

Based on the above equation, the lower retention time of $\mathrm{RDB}\left(\mathrm{Y}_{5}\right)$ can be obtained by increasing flow rate $\left(X_{3}\right)$. The increasing $X_{1}$ and $X_{2}$ also lower $Y_{5}$. The column temperature $\left(\mathrm{X}_{4}\right)$ has not significantly increased $\mathrm{Y}_{5}$. The statistical results revealed that adjusted coefficient of determination (Adj. $\mathrm{R}^{2}$ ) obtained was $>0.8$, which was within the acceptable limits $\left(\mathrm{R}^{2}>0.8\right)$. This indicated that experimental model was fit using polynomial equations (Sadhukan et al., 2016). The variables of $\mathrm{X}_{1}, \mathrm{X}_{2}$ and $\mathrm{X}_{3}$ as well as interaction between $\mathrm{X}_{1} . \mathrm{X}_{2}$ and $X_{2} . X_{3}$ and quadratic form of $X_{1}, X_{2}$ and $X_{4}$ contributed significantly for response of $\mathrm{Y}_{5}(\mathrm{P}<$ 0.05). Figure 6 exhibited the contour plot of retention time of $\mathrm{RDB}$ and $3 \mathrm{D}$ surface graph as a results of variables of $\mathrm{X}_{1}, \mathrm{X}_{2}, \mathrm{X}_{3}$, and $\mathrm{X}_{4}$. Based on Fig.6, the higher acetonitrile ratio and the higher $\mathrm{pH}$ buffer phosphate, the lower retention time of RDB.

\section{Response of peak area of carmine $\left(\mathrm{Y}_{6}\right)$}

Based on ANOVA results, the equation obtained for the relationship between $\mathrm{X}_{1}, \mathrm{X}_{2}, \mathrm{X}_{3}$, and $\mathrm{X}_{4}$ as independent variables with peak area of CAR $\left(\mathrm{Y}_{6}\right)$ was:

$\mathrm{Y}_{6}=-1.43 \mathrm{E}+05+62098.49 \mathrm{X}_{1}+4976.03 \mathrm{X}_{2}-$ $1.77 \mathrm{E}+05 \mathrm{X}_{3}+5970.04 \mathrm{X}_{4}+27.92 \mathrm{X}_{1} \mathrm{X}_{2}+$ $22814.58 \mathrm{X}_{1} \mathrm{X}_{3}-643.25 \mathrm{X}_{1} \mathrm{X}_{4}-813.75 \mathrm{X}_{2} \mathrm{X}_{3}-$ $35.83 \mathrm{X}_{2} \mathrm{X}_{4}+433.75 \mathrm{X}_{3} \mathrm{X}_{4}-9553.59 \mathrm{X} 1^{2}-26.45 \mathrm{X} 2^{2}+$ $29667.71 X^{2}-30.05 X 4^{2} \quad$ (Adjustable $R^{2}=0.9592$ ) (Eq. 6)

Based on the above equation, the higher peak area of CAR $\left(\mathrm{Y}_{6}\right)$ can be obtained by increasing $\mathrm{pH}$ buffer phosphate $\left(\mathrm{X}_{1}\right)$ and decreasing flow rate $\left(\mathrm{X}_{3}\right)$. The variables of $\mathrm{X}_{3}$ as well as interaction between $\mathrm{X}_{1}$ and $\mathrm{X}_{3}\left(\mathrm{X}_{1} . \mathrm{X}_{3}\right)$ and quadratic form of $\mathrm{X}_{1}$ contributed significantly for response of $\mathrm{Y}_{6}$ $(\mathrm{P}<0.05)$. Figure 7 exhibited the contour plot of retention time of CAR and 3D surface graph as a results of variables of $\mathrm{X}_{1}, \mathrm{X}_{2}, \mathrm{X}_{3}$, and $\mathrm{X}_{4}$. The change of acetonitrile ratio and $\mathrm{pH}$ buffer phosphate did not influence the retention time of CAR significantly.

\section{Response of peak area of Rhodamine $B\left(\mathrm{Y}_{7}\right)$}

Eq. 7 revealed the response of peak area of $\mathrm{RDB}\left(\mathrm{Y}_{7}\right)$ describing the relationship between $\mathrm{X}_{1}$, $\mathrm{X}_{2}, \mathrm{X}_{3}$, and $\mathrm{X}_{4}$ as independent variables with peak area of RDB (Y7).

$\mathrm{Y}_{7}=2.88 \mathrm{E}+05+23156.39 \mathrm{X}_{1}+401.1 \mathrm{X}_{2}-$ $1.82 \mathrm{E}+05 \mathrm{X}_{3}+345.93 \mathrm{X}_{4}$ (Adjusted $\mathrm{R}^{2}=0.9788$ ) (Eq.7)

Based on the above equation, the higher peak area of $\mathrm{RDB}\left(\mathrm{Y}_{7}\right)$ can be obtained by increasing pH buffer phosphate $\left(\mathrm{X}_{1}\right)$ and decreasing flow rate $\left(X_{3}\right)$. The statistic results for $Y_{7}$ informed that adj. $\mathrm{R}^{2}$ was $>0.8$. The variables of $\mathrm{X}_{1}$ and $\mathrm{X}_{3}$ contributed significantly for response of $\mathrm{Y}_{3} \quad(\mathrm{P}<0.05)$. The variables of $\mathrm{X}_{1}$ and $\mathrm{X}_{3}$ affected positively, meaning that the increased levels of $\mathrm{pH}$ Buffer $\left(\mathrm{X}_{1}\right)$ and flow rate $\left(X_{3}\right)$ would increase peak area of $\mathrm{RDB}$ (increased sensitivity). The contour plot along with along with 3D surface graph of peak area of RDB was shown in Figure 8. The change of acetonitrile ratio and $\mathrm{pH}$ buffer phosphate did not influence the peak area of RDB.

Based on Eq.7, among four independent variables, $\mathrm{pH}$ buffer phosphate $\left(\mathrm{X}_{1}\right)$ and flow rate $\left(\mathrm{X}_{4}\right)$ has significant influence on the responses $(\mathrm{Y})$. The positive effect of increasing $\mathrm{pH}$ buffer phosphate $\left(\mathrm{X}_{1}\right)$ was decreasing tailing factor CAR $\left(\mathrm{Y}_{2}\right)$ and increasing peak area of CAR (Y6). The negative effects of higher value of flow rate are decreasing resolution $\left(\mathrm{Y}_{1}\right)$, peak area of CAR $\left(\mathrm{Y}_{6}\right)$, and peak area of RDB $\left(\mathrm{Y}_{7}\right)$ and increasing tailing factor of CAR $\left(\mathrm{Y}_{2}\right)$, whereas the positive effect is decreasing the retention time of CAR and RDB. Based on the Figure 2-7, the decreasing acetonitrile ratio and the increasing $\mathrm{pH}$ buffer phosphate have some positive effects, such as higher value of resolution and the lower value of tailing factor of CAR and tailing factor of RDB.

The optimum predicted conditions for separation of CAR and RDB based on the statistical results was as follows: pH buffer 3.4, ACN 55\%, flow rate of $1.1 \mathrm{~mL} / \mathrm{min}$ and column temperature of $35^{\circ} \mathrm{C}$ with desirability of 1 . It means that $100 \%$ data can be described by selected model, and the desired response would be reached easily. The HPLC chromatogram obtained using this optimum condition was shown in Figure 9. It is clear that CAR and RDB were clearly separated using RP-HPLC 
using optimum condition, as suggested by the experimental design of central composite design (CCD).

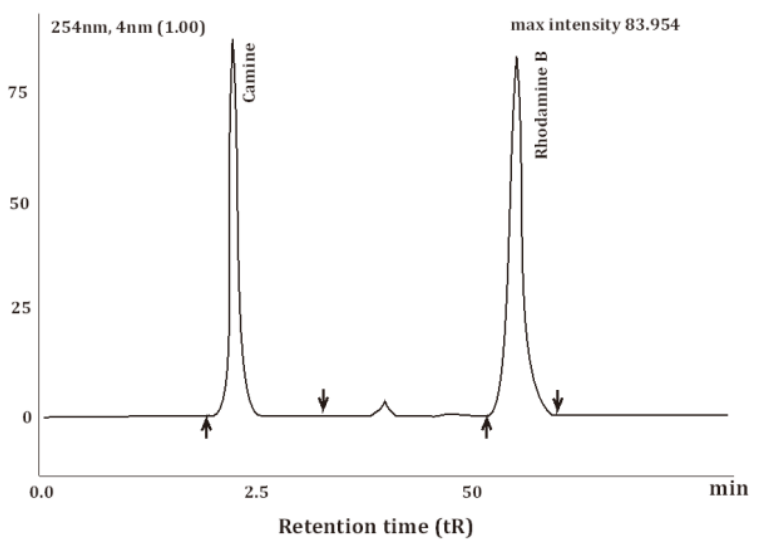

Figure 9. The separation of carmine and rhodamine $B$ using the optimized RP-HPLC condition as suggested by central composite design (CCD). See text for optimum condition of RP-HPLC.

\section{CONCLUSION}

Central composite design (CCD) showed that separation of CAR and RDB was influenced by $\mathrm{pH}$ buffer phosphate, ratio of acetonitrile, flow rate and column temperature. The optimum predicted conditions for separation of CAR and RDB was $\mathrm{pH}$ buffer 3.4 , ACN $55 \%$, flow rate of $1.1 \mathrm{~mL} / \mathrm{min}$ and column temperature of $35^{\circ} \mathrm{C}$ with desirability of 1 . CAR and RDB were clearly separated using optimum condition, as suggested by CCD.

\section{ACKNOWLEDGEMENT}

The authors thank to the Ministry of Research and Higher Education and Directorate of Research and Community Services, Universitas Gadjah Mada for supporting the publication of this article through scheme of Penelitian Terapan Unggulan Perguruan Tinggi (PTUPT 2019) awarded to Prof. Dr. Abdul Rohman with contract number 2717/UN1.DITLIT/DIT-LIT/LT/2019.

\section{REFERENCES}

Allam KV. and Kumar GP. 2011. Colorants the cosmetics for the pharmaceutical dosage forms. Int J Pharm Pharm Sci,; 3: 13-21.

Bezerra MA., Santelli RE., Oliveira EP., Villar LS. and Escaleira LA. 2008; Response surface methodology (RSM) as a tool for optimization in analytical chemistry. Talanta, 76: 965-977.
DiCello MC., Myc A., Baker JR Jr. and Baldwin JL. 1999;Anaphylaxis after ingestion of carmine colored foods: two case reports and a review of the literature. Allergy Asthma Proc, 20: 377-382.

Feng F., Zhao Y., Yong W., Sun L., Jiang G. and Chu X. 2011. Highly sensitive and accurate screening of 40 dyes in soft drinks by liquid chromatography-electrospray tandem mass spectrometry. J Chromatogr B., 879: 18131818.

Gagliardi L., De Orsi D., Cavazzutti G., Multari G. and Tonelli D. 1996. HPLC determination of rhodamine B (C.I. 45170) in cosmetic product. Chromatographia,; 43: 76-78.

Gonzalez M., Mendez J., Carnero A., Lobo MG. and Afonso A. 2002. Optimizing Conditions for the Extraction of Pigments in Cochineals (Dactylopius coccus Costa) using Response Surface Methodology. J Agric Food Chem,; 50: 6968-6974.

Kanekar H. and Khale A. 2014; Coloring Agents: Current Regulatory Perspective for Coloring Agents Intended for Pharmaceutical \& Cosmetic Use. Int J Pharm Phytopharmacol Res, 2: 1-20.

Li J., Ding XM., Liu DD., Guo F., Chen Y., Zhang YB. And Liu HM. 2013. Simultaneous determination of eight illegal dyes in chili products by liquid chromatographytandem mass spectrometry. J Chromatogr $B$ Analyt Technol Biomed Life Sci, 30; 942-943: 46-52.

Miranda-Bermudez E., Harp BP. and, Barrows JN. Qualitative Identification of Permitted and Non-permitted Color Additives in Cosmetics. J AOAC Int, 2014; 97: 1039-1047.

Miyakawa M. Inomata N., Sagawa N., Nomura Y., Yamaguchi Y. and Aihara M. 2017; Anaphylaxis due to carmine-containing foods induced by epicutaneous sensitization to red eye-liner. J Dermatol, 44: 96-97.

Nohynek GJ., Antignac E., Re T. and Toutain H. 2010; Safety assessment of personal care products/cosmetics and their ingredients. Toxicol Appl Pharmacol, 243: 239-259.

Prabaningdyah NK., Riyanto S., 2017; Rohman A. and Siregar C. Application of HPLC and response surface methodology for simultaneous determination of curcumin and desmethoxycurcumin in Curcuma syrup formulation. J App Pharm Sci, 7: 58-64.

Rastogi SC., Barwick VJ. and Carter SV. 1997; Identification of organic colourants in 
cosmetics by HPLC-diode array detection. Chromatographia, 45: 215-228.

Sadhukhan B., Mondal NK. and Chattoraj S. 2016; Optimisation Using Central Composite Design (CCD) and the desirability function for sorption of methylene blue from aqueous solution onto lemna major. Karbala Int $J$ Modern Sci, 2(3): 145-55.

Setyawan EH., Setyowati EP., Rohman A. and Nugroho AK. 2018; Central Composite Design for Optimizing Extraction of EGCG from Green Tea Leaf (Camellia sinensis L.). Int J App Pharm, 10: 211-216.

Shaji J. and Shah A. 2016; Optimization of Tenoxicam Loaded Niosomes Using Quadratic Design. Int J Curr Pharm Res, 8: 67-62

Siregar C., Prabaningdyah NK., Choiri S., Riyanto S. and Rohman A. 2018; Optimization of HPLC Using Central Composite Design for Determination of Curcumin and Demethoxycurcumin in Tablet Dosage Form. Dhaka Univ J Pharm Sci, 16: 137-45.
Sun HW. and Wang FC., Ai LF. 2007; Determination of banned 10 azo-dyes in hot chili products by gel permeation chromatography-liquid chromatography-electrospray ionizationtandem mass spectrometry. J Chromatogr A, 1164:120-128.

Tatebe C., Zhong X., Ohtsuki T., Kubota H., Sato K. and Akiyama H. 2014; A simple and rapid chromatographic method to determine unauthorized basic colorants (rhodamine B, auramine 0 , and pararosaniline) in processed foods. Food Sci Nutr, 2: 547-556.

Wang J., Jia Q, et al. 2015; Preparation of a zeolitemodified polymer monolith for identification of synthetic colorants in lipsticks. Appl Surface Sci, 353: 1326-1333

Weisz A., Milstein SR., Scher AL., Hepp NM. 2018; Colouring Agents in Cosmetics: Regulatory Aspects and Analytical Methods in Analysis of Cosmetic Products, 123-157, Elsevier, USA. 